\title{
Mode of Action and Antibacterial Activity of Ethanolic Ant Plant Tuber Extract Inhibiting Growth of Staphylococcus aureus and Escherichia coli
}

\author{
Theera SRISAWAT ${ }^{1, *}$, Narueparn SUKKASAM ${ }^{2}$, Jirawadee UPPALA ${ }^{2}$, \\ Chananchita NILAKE ${ }^{2}$, Kanokrat KEAWCHAI ${ }^{3}$, Amita CHUJAN $^{3}$, \\ Chuthapond MUSIMUN ${ }^{3}$, Parinuch CHUMKAEW ${ }^{4}$ and Patima PERMPOONPATTANA ${ }^{3}$
}

\author{
${ }^{1}$ Faculty of Science and Industrial Technology, Prince of Songkla University, Suratthani Campus, \\ Surat Thani 84000, Thailand \\ ${ }^{2}$ Wittayanusorn Suratthani School, Muang, Surat Thani 84000, Thailand \\ ${ }^{3}$ Department of Agricultural Science and Technology, Faculty of Science and Industrial Technology, \\ Prince of Songkla University, Surat Thani Campus, Surat Thani 84000, Thailand \\ ${ }^{4}$ Department of Applied Chemistry, Prince of Songkla University, Surat Thani Campus, \\ Surat Thani 84000, Thailand
}

('Corresponding author's e-mail: theera.s@psu.ac.th)

Received: 17 December 2019, Revised: 27 April 2021, Accepted: 30 April 2021

\begin{abstract}
The present study aimed to investigate the activity of Hydnophytum formicarum Jack (Ant Plant) tuber extract against Staphylococcus aureus and Escherichia coli and the mode of action of the extract on bacterial responses. The antibacterial activity was determined using agar well diffusion method. Resazurin-based 96-well microdilution method was used to determine the Minimal Inhibitory Concentrations (MIC) of the extract. Mode of action on bacterial death and response patterns to the extract were assessed by flow cytometry using membrane integrity and granularity profiles. The results, based on serial dilution and zones of inhibition against the bacteria, showed that $2,000 \mu \mathrm{g} / \mathrm{well}$ was potent against $S$. aureus $(16.33 \pm 1.53 \mathrm{~mm})$ and $E$. coli $(14.33 \pm 0.58 \mathrm{~mm})$. For $S$. aureus, the MIC concentration was $8,000 \mu \mathrm{g} / \mathrm{mL}$, while $4,000 \mu \mathrm{g} / \mathrm{mL}$ concentration exhibited activity against $E$. coli. Flow cytometric profiles confirmed loss of intracellular components, followed by death, for both bacteria. Bacterial responses to the extract had consistent dose- and time-dependent behavior. This is the first mode of action study on bacterial responses to $H$. formicarum tuber extract. The results suggest that the extract of $H$. formicarum tuber could serve as a source of an initial active ingredient for developing effective medicines to battle infections caused by pathogens.
\end{abstract}

Keywords: Antibacterial activity, Flow cytometry, Hydnophytum formicarum, Bacterial response, Resazurin assay

\section{Introduction}

The emergence of antibiotic resistant bacteria (ARB) increases public health risks and is largely due to the overuse and misuse of antibiotics, as well as a lack of new antibiotics from the pharmaceutical industry [1]. ARB strains can cause various infections, such as gastritis, urinary tract infections (UTIS), encephalitis, and food poisoning [2,3]. In addition, the World Health Organization (2014) reported that ARB strains are now considered a major threat to public health, because common antibiotics might not cure ARB infections. Development of new antibiotics has been declining rapidly over the past decades, and only two antibiotics were approved during 2008-2012 (Boucher et al., 2013 cited by [4]), due to 
http://wjst.wu.ac.th

decreasing research and development of antibiotics by the major pharmaceutical companies. Thus, it is of interest to find new alternatives; for example, from medicinal plants. Medicinal plants have valuable phytochemicals that can be used as bactericides [5] and can be effective in defense against infectious diseases with only mild side effects.

At present, many parts of plants in the family Rubiaceae have been subjected to medicinal studies [6-8]. For example, tuber of Hydnophytum formicarum Jack (one of the Myrmecophytes species that provide ant housing places at modified stem, with various interactions between them) has reportedly antibacterial properties against some gram positive and negative bacteria [9-11]. In spite of many studies reporting the effects of $H$. formicarum tuber extracts against various bacteria, little is known about the pattern of bacterial response. This study investigated the antibacterial activity of ethanol extract from tuber of H. formicarum against the gram positive bacterium, Staphylococcus aureus, and the gram negative bacterium, Escherichia coli, and the mode of action by assessing the patterns of the bacterial responses.

\section{Materials and methods}

\section{Preparation of $\boldsymbol{H}$. formicarum tuber extract}

Dried powder tuber sample of $H$. formicarum was procured by a traditional healer. Briefly, plant sample was collected in the Northeastern region of Thailand. Then, the sample was cut before drying. The dried sample was suspended in $95 \%$ ethyl alcohol for 5 days, and then the suspension was filtered with 2 cotton layers. The ethanol filtrate was collected and concentrated in a rotary evaporator at $45{ }^{\circ} \mathrm{C}$ until a sticky mass was obtained. The extract was transferred to a dark glass bottle and stored in a cool, dark place.

\section{Microorganisms tested}

The bacterial strains tested for the antibacterial activity of $H$. formicarum extract were $S$. aureus (ATCC25923) and E. coli (ATCC25922). These bacterial strains were maintained at the Scientific Laboratory and Equipment Center (SLEC), Prince of Songkla University, Surat Thani campus, Thailand.

\section{Agar well diffusion}

The antibacterial activity was measured using the agar-well diffusion method on Mueller-Hinton Agar (MHA). The bacterial isolates were sub-cultured in nutrient broth (NB) for $18 \mathrm{~h}$ prior to transferring to the MHA medium. Briefly, sterile cotton swabs were dipped into the bacterial strain suspensions $\left(1 \times 10^{7} \mathrm{CFU} / \mathrm{mL}\right)$, and then the whole surface of an agar plate was inoculated $(25 \mathrm{~mL}$ medium $)$. A hole with $6 \mathrm{~mm}$ diameter was punched aseptically with a sterile cork borer, and $50 \mu \mathrm{L}$ of the extract solution at desired concentrations $(50-2,000 \mu \mathrm{g} /$ well) was introduced into the well. The plates with bacterial cultures were incubated at $37^{\circ} \mathrm{C}$ for $24 \mathrm{~h}$. The antibacterial effects of the extract on bacteria were evaluated using Ciprofloxacin (CF) at $30 \mu \mathrm{g} / \mathrm{mL}$ concentration as the positive control.

Determination of minimum inhibitory concentration (MIC), with resazurin-based 96-well microdilution, and minimum bactericidal concentration (MBC)

The method described by Elshikh et al. [12] was slightly modified. Bacterial suspension at mid-log phase was used. The first well had $280 \mu \mathrm{L}$ of mixed solution with Mueller Hinton Broth (MHB) and 2fold extract concentration $(8,000 \mu \mathrm{g} / \mathrm{mL})$. Wells 2 - 9 had $140 \mu \mathrm{L}$ MHB. To prepare extract concentration from 8,000 to $31.25 \mu \mathrm{g} / \mathrm{mL}, 140 \mu \mathrm{L}$ aliquot from the first well was pipetted and added into the next well to make 2-fold serial microdilution in the 96 -well plate. $50 \mu \mathrm{L}$ of bacterial suspension was added into each well, except for well 12. Wells 10 and 11 had negative (Dimethyl sulfoxide) and positive (30 $\mu \mathrm{g} / \mathrm{mL}$ Ciprofloxacin) control treatments. The 96 -well plate was then incubated at $37^{\circ} \mathrm{C}$ for $24 \mathrm{~h}$ before adding $10 \mu \mathrm{L}$ of $0.015 \%$ resazurin and incubating for $1-2 \mathrm{~h}$ prior to evaluation of color. 


\section{Assessing the mode of action and response patterns by flow cytometry}

The mode of action and response patterns of bacteria to extract were determined following Musimun et al. [13]. Briefly, bacterial strains were harvested at mid-logarithmic phase $\left(1 \times 10^{7} \mathrm{CFU} / \mathrm{mL}\right)$ and washed twice with $10 \mathrm{mM}$ Phosphate Buffer Saline (PBS). After centrifuging, the bacterial pellets were exposed to a range of $H$. formicarum extract concentrations $(2,000 ; 4,000 ;$ and $8,000 \mu \mathrm{g} / \mathrm{mL})$ and incubated at $37^{\circ} \mathrm{C}$ for $0,6,12$, and $24 \mathrm{~h}$. After incubation, each sample was centrifuged and washed twice with $10 \mathrm{mM}$ PBS. Finally, the bacterial pellet was resuspened with $950 \mu \mathrm{L}$ PBS prior to mixing with 50 $\mu \mathrm{L}$ propidium iodide (PI) at a final concentration of $30 \mu \mathrm{g} / \mathrm{mL}$ PI before testing with flow cytometry. The flow cytometer used was BD FACSCalibur (Becton Dickinson Biosciences (BDB), San Jose, CA). Acquisition and storage logged 10,000 events per sample using CELLQUEST software (BDB). The density plot diagrams used display logarithmic signal of each cell, with the Y-axis showing side scatter (SSC) and fluorescence signals (FL2-H) displayed along the X-axis. The density plot diagrams were generated with WinMDI version 2.9 software (Scripps Institute, La Jolla, CA) to evaluate the proportions of viable cells, membrane-damaged cells, injured cells, and dead cells.

\section{Results and discussion}

Antibacterial activity assay

Table 1 shows the antibacterial activities of the ethanolic ant plant tuber extract against $S$. aureus and E. coli. The extract concentrations from serial dilution displayed inhibition zones against both bacteria, from which $2,000 \mu \mathrm{g} /$ well was found potent against $S$. aureus $(16.33 \pm 1.53 \mathrm{~mm})$ and E. coli $(14.33 \pm 0.58 \mathrm{~mm})$, while lesser inhibition zones were exhibited by lower extract concentrations.

Table 1 Inhibition zones from agar-well diffusion method for ant plant tuber extract against $S$. aureus and E. Coli.

\begin{tabular}{ccc}
\hline \multirow{2}{*}{ Concentration $(\boldsymbol{\mu g} /$ well $)$} & \multicolumn{2}{c}{ Zone of inhibition (Mean \pm SD, $\mathbf{~ m m})$} \\
\cline { 2 - 3 } & S. aureus & $\boldsymbol{E}$. coli \\
\hline 50 & $6.33 \pm 0.58^{\mathrm{d}}$ & $7.33 \pm 0.58^{\mathrm{f}}$ \\
100 & $8.33 \pm 2.08^{\mathrm{d}}$ & $10.67 \pm 1.53^{\mathrm{cd}}$ \\
250 & $11.33 \pm 0.58^{\mathrm{c}}$ & $8.00 \pm 1.00^{\mathrm{ef}}$ \\
500 & $12.33 \pm 0.58^{\mathrm{c}}$ & $9.33 \pm 0.58^{\mathrm{de}}$ \\
1,000 & $12.67 \pm 1.53^{\mathrm{c}}$ & $12.33 \pm 1.15^{\mathrm{c}}$ \\
2,000 & $16.33 \pm 1.53^{\mathrm{b}}$ & $14.33 \pm 0.58^{\mathrm{b}}$ \\
Ciprofloxacin $(\mathrm{CF})$ & $37.00 \pm 1.00^{\mathrm{a}}$ & $37.00 \pm 1.00^{\mathrm{a}}$ \\
$10 \%$ DMSO & $\mathrm{NI}$ & $\mathrm{NI}$ \\
\hline
\end{tabular}

NI: No inhibition.

Values followed by the same superscript letter in a column did not differ statistically significantly (significance means $p<0.05$ ).

\section{Resazurin-based 96-well microdilution}

The MIC and MBC were determined. MICs of 8,000 and $4,000 \mu \mathrm{g} / \mathrm{mL}$ for the ant plant tuber extract were found against $S$. aureus and E. coli, respectively (Table 2 and Figure 1). On the other hand, no $\mathrm{MBC}$ was detected against either bacteria. 
http://wjst.wu.ac.th

Table 2 Minimum inhibitory concentration (MIC) with resazurin-based 96-well microdilution, and minimum bactericidal concentration (MBC) for $S$. aureus and E. coli treated by extract of ant plant.

\begin{tabular}{lcc}
\hline Bacteria & MIC & MBC \\
\hline S. aureus & $8,000 \mu \mathrm{g} /$ well & ND \\
E. coli & $4,000 \mu \mathrm{g} /$ well & ND \\
\hline
\end{tabular}

ND: Not detectable

(a)

A

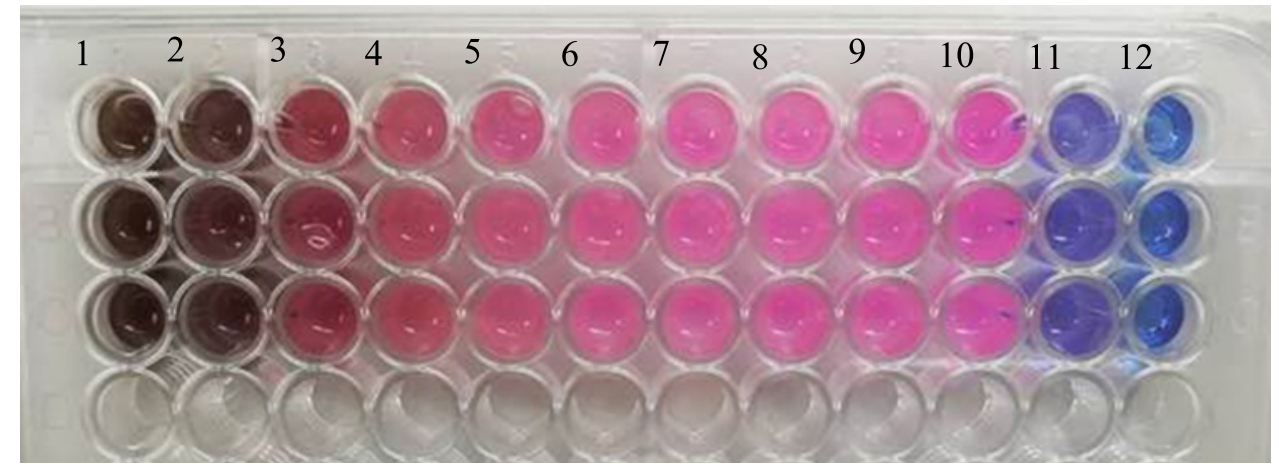

(b)

A

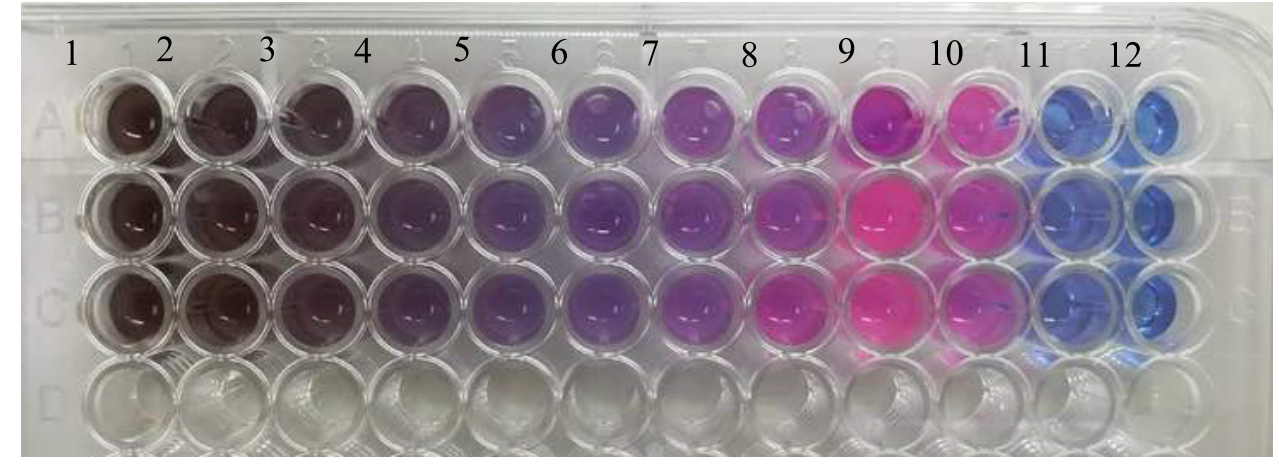

Figure 1 Determination of the MIC for ant plant tuber extract against $S$. aureus (a), and E. coli (b), with 3 replicate wells (A B C). Column $1(8,000 \mu \mathrm{g} / \mathrm{mL})$ confirms $S$. aureus was inhibited by the extract, while columns 1 and $2(8,000$ and 4,000 $\mu \mathrm{g} / \mathrm{mL})$ exhibited activity against E. coli. Column 10 for a negative control (DMSO) shows the change of resazurin to resorufin by growth of bacteria. Columns $11-12$ are for positive controls (Ciprofloxacin and NB without bacteria) and show stability of resazurin natural color. Columns 1 - 9 represent 8,000 to $31.25 \mu \mathrm{g} / \mathrm{mL}$ dose levels.

\section{Flow cytometric analysis}

To determine how the ant plant tuber extract causes $S$. aureus and $E$. coli death, in terms of mode of action and response pattern, PI-fluorescence (FL2-H) and side scatter (SSC) were used to monitor membrane integrity and entire granularity, respectively. The patterns of bacterial response were identified as follows: Injured cells (cells lost granularity) and dead cells (cells initially lost granularity, followed by loss of membrane integrity) are seen in the upper left quadrant (PI-negative, SSC-positive) and in the upper right quadrant (PI-positive, SSC-positive), respectively, whereas cells that lost membrane integrity are positioned in the lower right quadrant. 
Staphylococcus aureus and Escherichia coli were treated with a few concentrations $(2,000 ; 4,000$; and $8,000 \mu \mathrm{g} / \mathrm{mL}$ ) of ant plant tuber extract for 0 to $24 \mathrm{~h}$, and the proportions of viable and responding cells were determined. The proportion of responsive $S$. aureus and E. coli cells increased continuously with concentration and with incubation time (Figures 2 - 3). The $4,000 \mu \mathrm{g} / \mathrm{mL}$ extract was the most effective against $E$. coli at $0,6,12$, and $24 \mathrm{~h}$ of incubation, with injured cells and dead cells continuously increasing (5.9-15.2-18.5-35.9\% and 2.8-8.6-14.3-24.7\%, respectively) while the viable cells decreased (90.6-74.7-66.7-38.6\%) gradually (Figure 2). The highest percentage of responding E. coli cells was $61.4 \%$ when treated with the ant plant extract at $4,000 \mu \mathrm{g} / \mathrm{mL}$ and incubated for $24 \mathrm{~h}$. E. coli responded significantly to the extract in a dose- and time-dependent manner (Figure 2). On the other hand, when $S$. aureus was treated with the ant plant extract at the concentrations 2,000, 4,000, and 8,000 $\mu \mathrm{g} / \mathrm{mL}$ for 24 $\mathrm{h}$, the percentages of responding cells were $6.0,16.1$, and $17.3 \%$, respectively, showing consistent dosedependence. At $12 \mathrm{~h}$ incubation time, the highest fraction of responding S. aureus cells was $55.1 \%$, obtained with 4,000 $\mu \mathrm{g} / \mathrm{mL}$ ant plant extract (Figure 3). Unfortunately, other concentrations and incubation times were ineffective against $S$. aureus. The fluorescent density plots of ant plant extracttreated E. coli and S. aureus cells stained with PI are shown in Figures 2 - 3. These results indicate that the intracellular components of both S. aureus and E. coli suffered damage that increased with the concentration of ant plant tuber extract and time of incubation. No membrane-damaged cells were found among the treated bacteria $(<1.8 \%)$. Ciprofloxacin efficacy appeared to be a consequence of bacterial membrane damage, which was not associated with the ant plant extract.

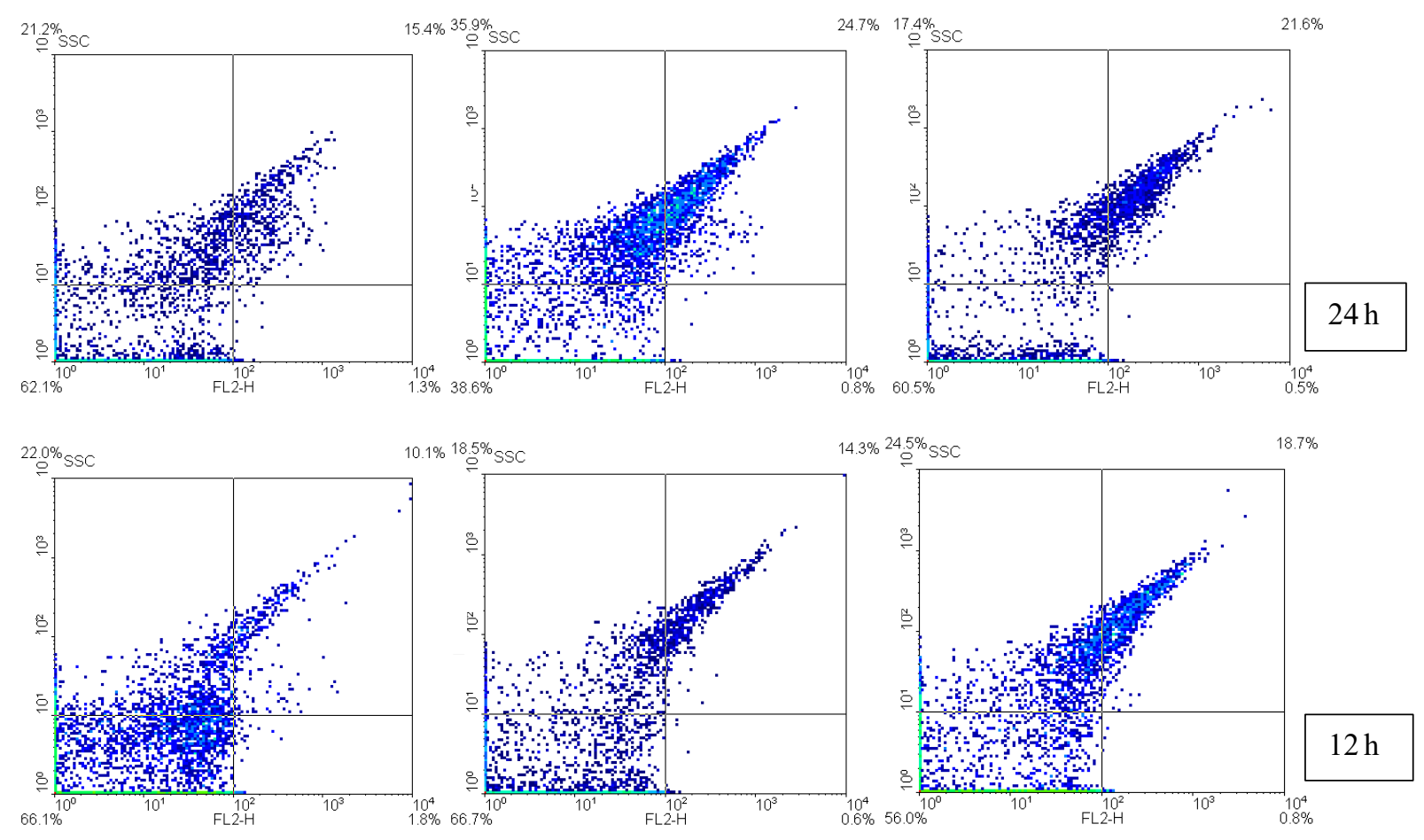




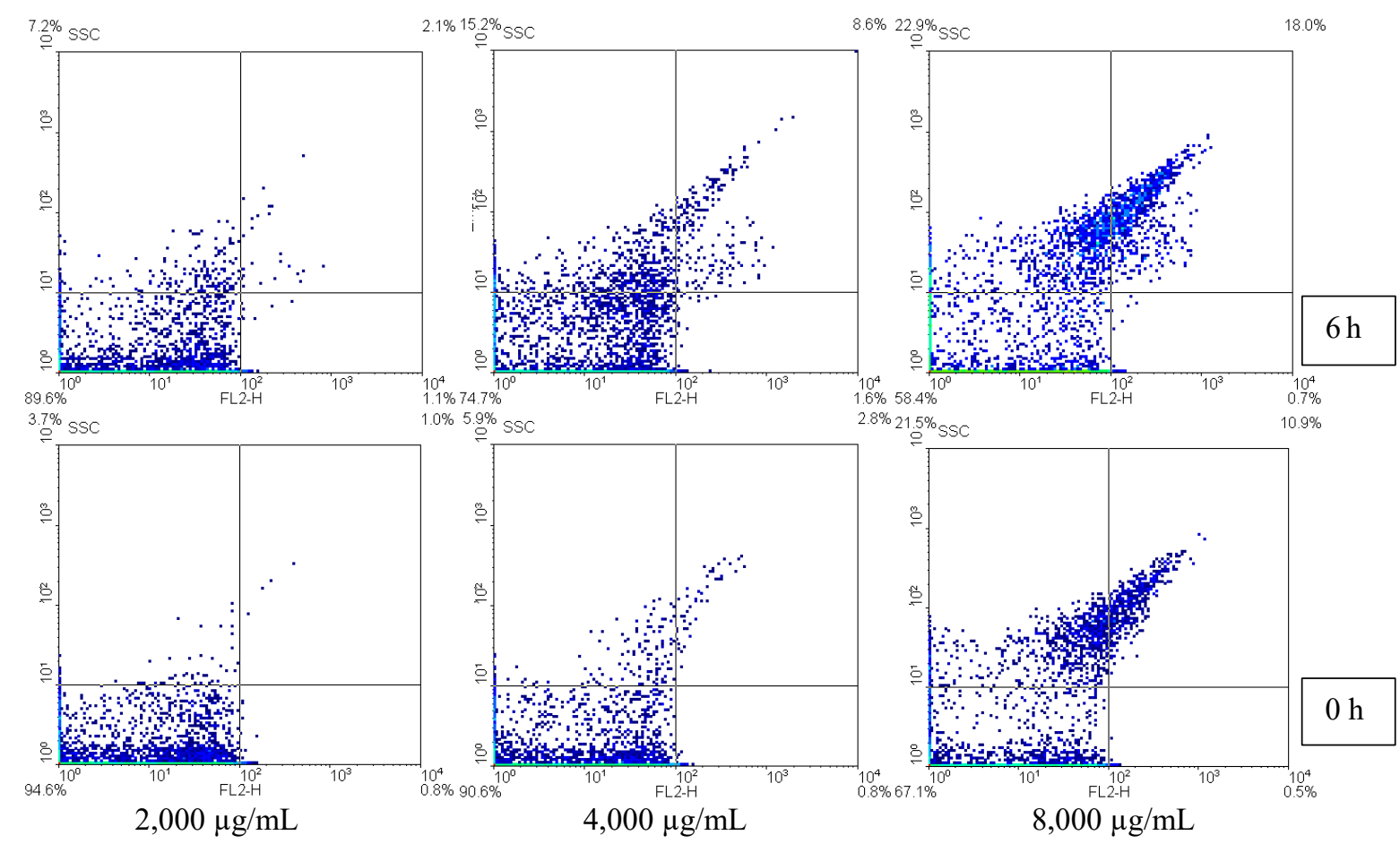

Figure 2 Flow cytometric profiles of E. coli response after exposure to various concentrations $(2,000$; 4,000 ; and $8,000 \mu \mathrm{g} / \mathrm{mL}$ ) of ant plant tuber extract and incubation for $0-24 \mathrm{~h}$.

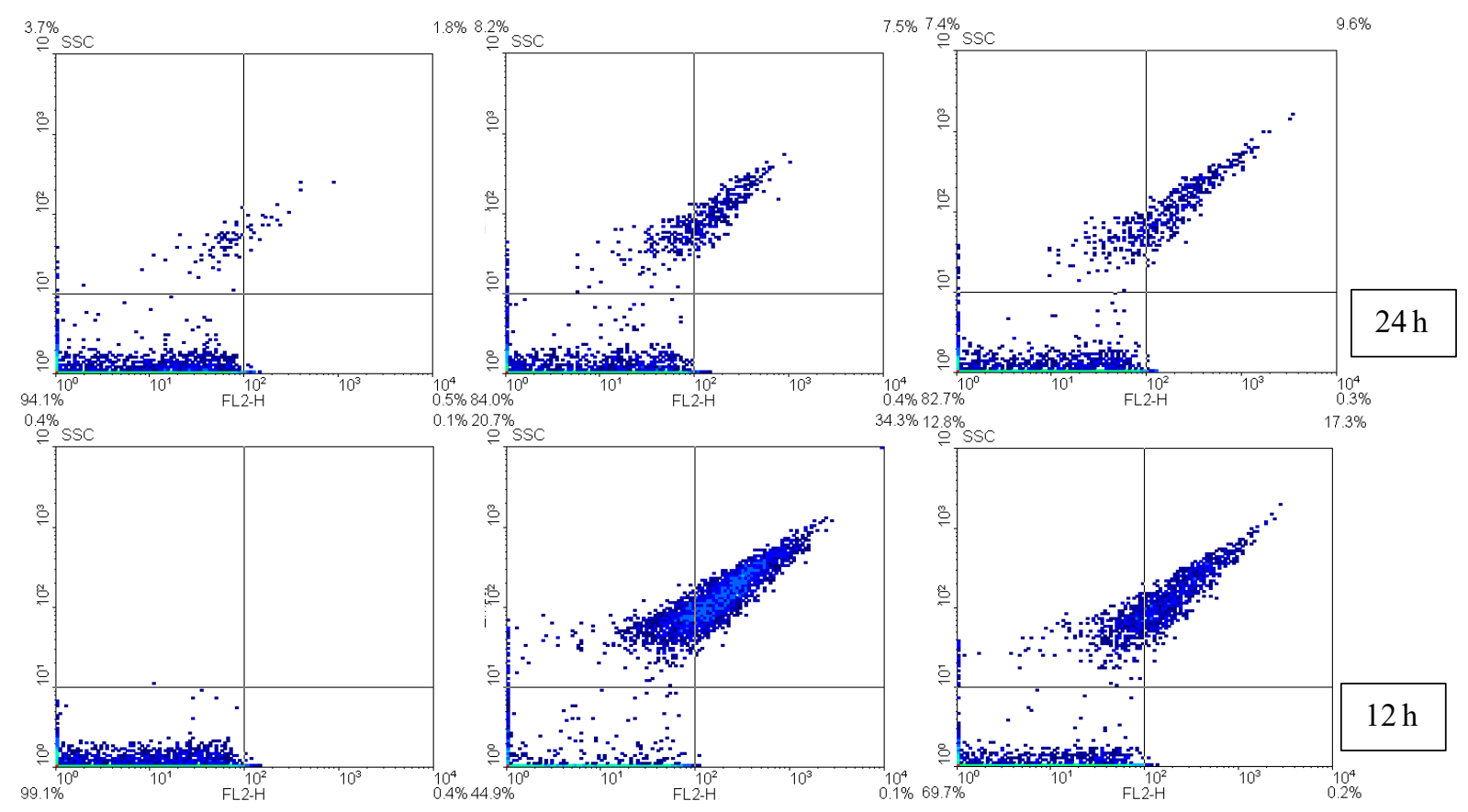




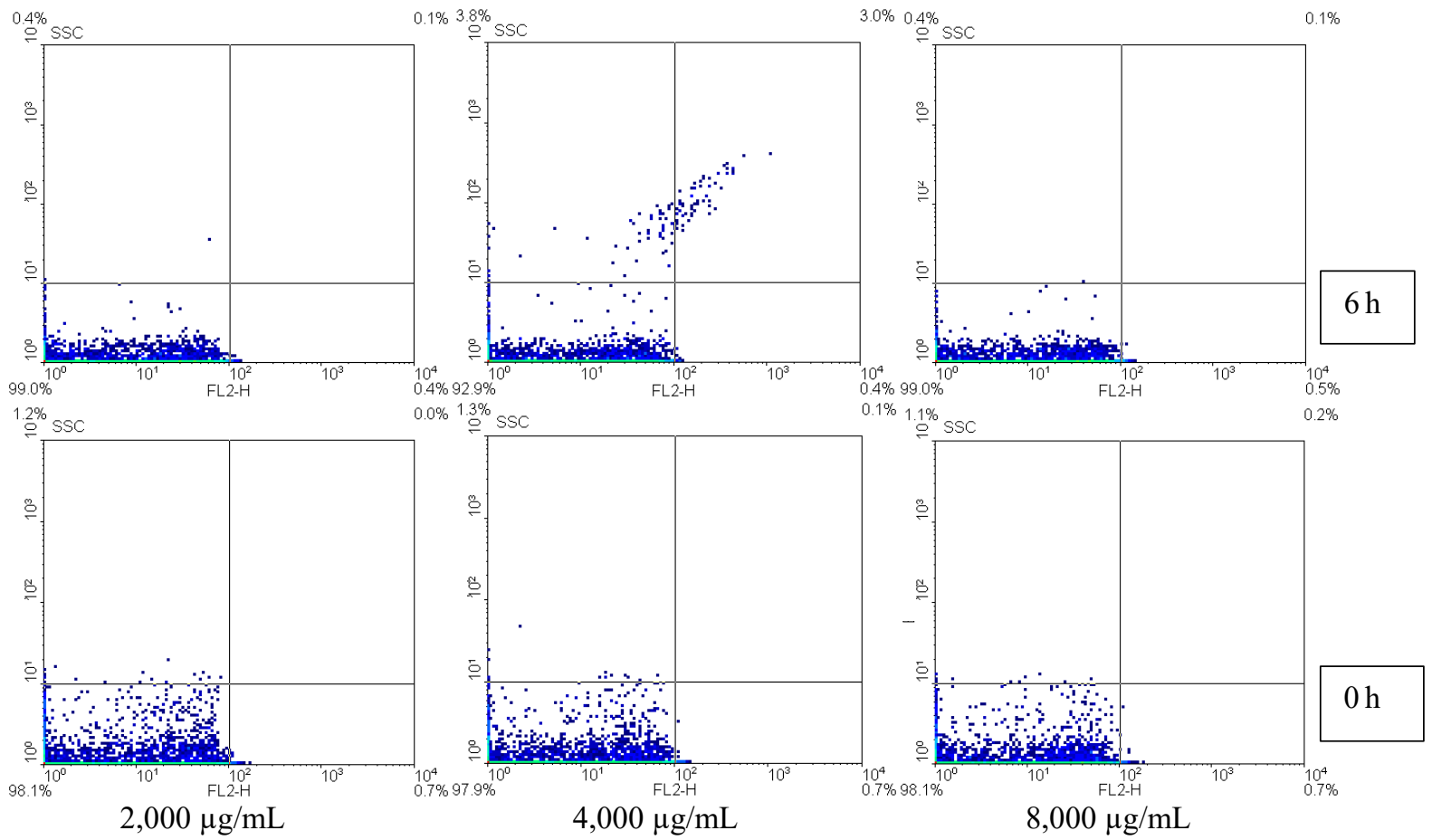

Figure 3 Flow cytometric profiles of $S$. aureus response after exposure to various concentrations $(2,000$; 4,000 ; and $8,000 \mu \mathrm{g} / \mathrm{mL}$ ) of ant plant tuber extract and incubation for $0-24 \mathrm{~h}$.

\section{Discussion}

A previous report showed that ant plant ethanolic tuber extract exhibited low antibacterial activity against both $S$. aureus and $E$. coli [10]. This has been attributed to variations observed in antibacterial efficacy between different habitats for ant plant growth [14], although seasonal variations and plant varieties are also potential factors affecting the extract quality. In this study, we received the ant plant material from traditional healers, who collected plant samples from forests in the Northeastern region of Thailand. In the antibacterial activity tests, $S$. aureus was inhibited more than E. coli. This might be due to structure differences of the bacterial cell envelope between gram positive and gram negative bacteria, which affect permeabilization and membrane disruption after exposure to antibacterial agents $[15,16]$. Interestingly, the test of antibacterial activity using resazurin-based 96-well microdilution showed potent MIC levels for ant plant tuber extract. The MIC found for the extract was higher than those obtained in a previous study reported by Prajuabjinda et al. [10]. While the testing there was overall similar to this current study, the percentage of resazurin used and the incubation method used differ. The resazurin assay utilizing 96-well plate, as described by Drummond and Waigh [17], has a fixed $0.675 \%$ concentration of resazurin that is incubated with the bacterial cultures [18]. Since active bacterial cells will reduce the resazurin (blue) to resorufin (pink) rapidly [12], the associated incubation of bacteria with antibacterial agent and resazurin assay might cause reduced resazurin levels before bacterial death, and false negative results may be obtained. In this study, we used the method as modified by Elshikh et al. [12], in which a lower resazurin level (only $0.015 \%$ ) was used, and more was added after completion of incubation, followed by incubating for $1-2 \mathrm{~h}$ further before observation of color change. With this modification, visual inspection is still applicable to identify dead bacteria (provided MIC is exceeded) that are more sensitive to the plant extract [19]. Compared to S. aureus, in this study, E. coli had higher sensitivity to ant plant tuber extract when tested with the modified resazurin-based 96-well microdilution. 
Antibacterial potency has traditionally been assessed by microbiological methods, such as viable plate count and fluorescent microscopy. These techniques count only a small sample of the total population, and are slow, with poor precision [20]. In previous work, viability of bacterial cell was validated by flow cytometry for estimating bacterial response to plant extract [13]. Flow cytometric analysis associated with highly sensitive fluorescent DNA-specific dye, namely propidium iodide (PI), enhanced the detection and quantification of bacteria treated by antibacterial agent. PI is commonly used as a cell death marker because it is able to penetrate the bacterial membrane of a dying or dead cell [21]. However, while the loss of membrane integrity is observed as increased uptake of PI, some membrane damage might not be related to the death of bacteria [22]. Therefore, SSC counts after exposure to the extracts must be acquired to indicate interference with intracellular components, which also informs of cell death [13]. Using PI-staining and SSC parameters on flow cytometer is, thus, a key opportunity to evaluate the efficiency and the mode of action of an antibacterial agent, by observing the responding bacteria and dead cells.

The results in this study could be related to Programmed Cell Death (PCD) of bacteria after exposure to plant extract and self-digestion of the cell wall [13,23]. As described by Dwyer et al. [24], bactericidal agents can induce PCD via chromosome condensation and DNA fragmentation of bacteria, and loss of granularity (high SSC value) might be caused by the bactericidal agents. However, it is not clear whether PCD-related proteins, namely toxin and antitoxin, would induce PCD in the tested bacteria. Further studies should investigate, especially, the effects on intracellular enzymes and gene or protein expression. The results from flow cytometry confirmed that ant plant extract inhibited growth of the tested bacteria through intracellular destruction, subsequently leading to membrane damage and death. Interestingly, the manner in which ant plant extract inhibits bacteria is dependent on concentration and time of incubation.

The ant plant extract tested in this study was able to inhibit growth of both S. aureus and E. coli, which indicates it to be a potent source of antibacterial compound(s) that could be employed in pharmacology and medicine. Phytochemical analysis of ant plant tuber extract has revealed the presence of many bioactive compounds [9,25]. Some of these are antibacterial, but some have never been assessed for their biological activity [26]. We believe that these compounds, and crude extracts of ant plant tuber, could play an important role in the battle against ARBs in the near future.

\section{Conclusions}

In this study, the mode of action of ant plant tuber extract was explored against $S$. aureus and $E$. coli. Resazurin-based 96-well microdilution and flow cytometry allowed determination of the MIC values and assessment of patterns in the bacterial responses. The flow cytometry incorporated both PI-staining and side scatter plot profiles. Bacterial granularity damage exhibited remarkable ant plant action against both bacteria, and this might have caused the bacterial deaths. This study demonstrates an approach to, and encourages future research on, novel treatments against pathogens, and especially against those ARBs requiring new alternative treatments.

\section{Acknowledgements}

This work was financially supported by the Ministry of Science and Technology of Thailand for the Science Classrooms in University-Affiliated School Project and Prince of Songkla University, Surat Thani campus. We acknowledge Associate Professor Dr. Seppo J. Karrila for editing this manuscript. 
http://wjst.wu.ac.th

\section{References}

[1] CL Ventola. The antibiotic resistance crisis: Part 1: Causes and threats. Pharm. Therapeut. 2015; 40, 277-83.

[2] A Lee and J O'Rourke. Gastric bacteria other than Helicobacter pylori. Gastroenterol. Clin. North Am. 1993; 22, 21-42.

[3] A Mailles and JP Stahl. Infectious encephalitis in France in 2007: A national prospective study. Clin. Infect. Dis. 2009; 49, 1838-47.

[4] B Li and TJ Webster. Bacteria antibiotic resistance: New challenges and opportunities for implantassociated orthopaedic infections. J. Orthop. Res. 2018; 36, 22-32.

[5] B Chakraborty, A Nath, H Saikia and M Sengupta. Bactericidal activity of selected medicinal plants against multidrug resistant bacterial strains from clinical isolates. Asian Pac. J. Trop. Med. 2014; 7 , S435-S441.

[6] O Pederson, A Gurib-Fakim, H Subratty and A Adsersen. Pharmacological properties of seven medicinal plants of the Rubiaceae from Mauritius. Pharm. Biol. 1999; 37, 202-7.

[7] L Bore, T Honda and GW Gribble. Partial synthesis of 23-hydroxyursolic acid isolated from medicinal plants of the Rubiaceae family. Nat. Prod. Lett. 2002; 16, 273-6.

[8] S Sen and R Chakraborty. Meyna spinosa Roxb.: An unexplored ethnomedicinal plant. Int. J. Green Pharm. 2017; 11, S332-S337.

[9] S Prachayasittikul, P Buraparuangsang, A Worachartcheewan, C Isarankura-Na-Ayudhya, S Ruchirawat and V Prachayasittikul. Antimicrobial and antioxidative activities of bioactive constituents from Hydnophytum formicarum Jack. Molecules 2008; 13, 904-21.

[10] O Prajuabjinda, S Panthong and A Itharat. Antimicrobial activity of Thai medicinal preparation of Khampramong temple used for cancer treatment and its plant components. J. Med. Assoc. Thai. 2012; 95, S159-S165.

[11] T Hertiani and SUT Pratiwi,. Hydnophytum formicarum Jack ethanol extract modulates quorum sensing-controlled pathogenicity in Pseudomonas aeruginosa. Pak. J. Pharm. Sci. 2015; 28, 1691-7.

[12] M Elshikh, S Ahmed, S Funston, P Dunlop, M McGaw, R Marchant and IM Banat. Resazurin-based 96-well plate microdilution method for the determination of minimum inhibitory concentration of biosurfactants. Biotechnol. Lett. 2016; 38, 1015-9.

[13] C Musimun, M Chuysongmuang, P Permpoonpattana, P Chumkaew, Y Sontikul, N Ummarat and T Srisawat. FACS analysis of bacterial responses to extracts of Vatica diospyroides fruit show dose and time dependent induction patterns. Walailak J. Sci. Tech. 2017; 14, 883-91.

[14] Y Andriani, H Mohamad, MNI Kassim, ND Rosnan, DF Syamsumir, J Saidin, TST Muhammad and $\mathrm{H}$ Amir. Evaluation on Hydnophytum formicarum tuber from Setiu wetland (Malaysia) and Muara Rupit (Indonesia) for antibacterial and antioxidant activities, and anti-cancer potency against MCF-7 and HeLa cells. J. Appl. Pharm. Sci. 2017; 7, 030-037.

[15] TJ Silhavy, D Kahne and S Walker. The bacterial cell envelope. Cold Spring Harb. Perspect. Biol. 2010; 2, 1-16.

[16] N Malanovic and K Lohner. Gram-positive bacterial cell envelopes: The impact on the activity of antimicrobial peptides. Biochim. Biophys. Acta 2016; 1858, 936-46.

[17] AJ Drummond and RD Waigh. The development of microbiological methods for phytochemical screening. Recent Res. Dev. Phytochem. 2000; 4, 143-52.

[18] SD Sarker, L Nahar and Y Kumarasamy. Microtitre plate-based antibacterial assay incorporating resazurin as an indicator of cell growth, and its application in the in vitro antibacterial screening of phytochemicals. Methods 2007; 42, 321-4.

[19] DA Hudman and NJ Sargentini. Resazurin-based assay for screening bacteria for radiation sensitivity. SpringerPlus 2013; 2, 55.

[20] MR Brown, S Camezuli, RJ Davenport, E Petelenz-Kurdziel, L $\phi$ vreas and TP Curtis. Flow cytometric quantification of viruses in activated sludge. Water Res. 2015; 68, 414-22. 
http://wjst.wu.ac.th

[21] J Hong, W Guan, G Jin, H Zhao, X Jiang and J Dai. Mechanism of tachyplesin I injury to bacterial membranes and intracellular enzymes, determined by laser confocal scanning microscopy and flow cytometry. Microbiol. Res. 2015; 170, 69-77.

[22] R Pagan and B Mackey. Relationship between membrane damage and cell death in pressure-treated Escherichia coli cells: Differences between exponential- and stationary-phase cells and variation among strains. Appl. Environ. Microbiol. 2000; 66, 2829-34.

[23] K Lewis. Programmed death in bacteria. Microbiol. Mol. Biol. Rev. 2000; 64, 503-14.

[24] DJ Dwyer, DM Camacho, MA Kohanski, JM Callura and JJ Collins. Antibiotic-induced bacterial cell death exhibits physiological and biochemical hallmarks of apoptosis. Mol. Cell. 2012; 46, 56172 .

[25] T Senawong, S Misuna, S Khaopha, S Nuchadomrong, P Sawatsitang, C Phaosiri, A Surapaitoon and B Sripa. Histone deacetylase (HDAC) inhibitory and antiproliferative activities of phenolic-rich extracts derived from the rhizome of Hydnophytum formicarum Jack.: Sinapinic acid acts as HDAC inhibitor. BMC Complement. Altern. Med. 2013; 13, 232.

[26] NS Abdullah, WYW Ahmad and NA Sabri. New compounds from Hydnophytum formicarum young tubers. Malaysian J. Anal. Sci. 2017; 21, 778-83. 